\title{
VARIATIONS IN OCCUPATIONAL MORTALITY BETWEEN AND WITHIN THE SOCIAL CLASSES
}

\author{
BY \\ IAN SUTHERLAND, B.A., F.S.S. \\ (Institute of Social Medicine, Oxford)
}

(Received October 11, 1946)

It is nearly a century since the Registrar-General first classified deaths according to the occupation registered on the death certificate and published statistics relating thereto in official publications generally known as Occupational Mortality Supplements. These publications appeared at decennial intervals and contained data for triennial periods centred on a census year. In this way he was able to obtain the number and age of those exposed to risk in each occupation, and by taking three years' deaths the resulting occupational death rates were made more dependable. In 1911 fresh ground was broken because in that year he also graded each occupation according to its social and economic significance, and the concept of mortality according to social class has become increasingly familiar to students of public health. The Registrar-General established five social classes, of which Class I consists of the professional and well-paid occupations, Class III comprises skilled workers, and Class V the unskilled labourers, while II and IV are intermediate groups where the occupations are not readily assignable to one of the other three. It is, however, necessary to bear in mind the alterations subsequently made in this classification, which affect comparisons.

Prior to 1921 the workers-were classified on an industrial basis, but in that supplement and in the one for 1931 the grouping was more nearly occupational. The difference is important because previously the high mortality in some occupations was obscured by the inclusion of other workers employed in the same industry but not exposed to the same occupational risks. For example, clerical staff in the offices of coal mines were in 1911 classified to coal-mining, though clearly they were not subject to the risks of the underground workers. In 1921 they were reclassified to clerical work, which is a better occupational description.

It will be evident that the social grouping is at best only an approximation. But it has nevertheless great advantages in portraying broadly the influence of differing economic levels (and their associated social backgrounds) on mortality and morbidity. Its uses in connexion with mortality are well exemplified by the very valuable information contained in the supplement for 1931, which is commented on by Greenwood as follows:

"If one simply glances at the tables in the current report on occupational mortality one is impressed by the range of variation. I open the volume on the page which assesses professional occupations. The first entry is clergymen (Anglican), and their Standard Mortality Ratio is 69; the fourth is church, chapel, and cemetery officials, and their S.M.R. is 95. But it would be hard 
to detect an occupational hazard of the officials of churches, chapels, and cemeteries not shared by the clergy. Is there some other reason for the clerical advantage ? In the eighth column of the table from which I culled those figures one finds entered against 'clergy' the numeral $I$, and against ' church, etc., officials' the numeral III. Clergy are allocated to the highest of the social classes, and the officials to the third of the five formed. One has a particular case of the general rule that the rate of mortality increases as social status decreases."

It is, however, important to remember that each of the social classes enumerated by the Registrar-General consists of a conglomeration of occupations each with a certain economic and social background in some degree favourable or unfavourable to health. In addition to this environmental aspect there may be a specific occupational risk-for example, the striking silicosis risk among cutlery grinders and workers underground in tin mines. As a consequence the mortality rates for occupations within a given social class may show considerable variation. But there is a tendency to overlook this fact, since each social class is regarded and treated as a homogeneous unit. The purpose of the present study is to examine the amount of variation actually occurring in the mortality both within a social class and between the social classes.

\section{DATA}

The data on which the analysis was based were the standardized mortality ratios recorded for the various occupations in Table 6 of the Registrar-General's Decennial Supplement on Occupational Mortality for 1931. There is a certain amount of overlap among the occupational groups tabulated. For the purpose of the present analysis the smaller of the groups involved were ignored in abstracting the figures. Apart from these, each recorded standardized mortality ratio for certain selected diseases was assigned to its appropriate social classification. In order to show the social differences more clearly Classes I and II were combined to represent the highly favoured economic group; similarly IV and V were aggregated and represent the least-favoured. The specific diseases selected for analysis were:

$\quad$ Men
Pulmonary tuberculosis
Cancer (all sites)
Peptic ulcer
Bronchitis
Angina pectoris
Diabetes
Appendicitis
Influenza

Wives

Pulmonary tuberculosis

Uterine cancer

Puerperal causes

Bronchitis

Breast cancer

Influenza

The reasons for this selection are that these diseases are numerically important as causes of death; also some of them have a marked gradient, either positive or negative, with social class, whereas others have no obvious trend. Examples of these three types are pulmonary tuberculosis, appendicitis, and influenza, respectively.

At this stage it is desirable to describe the standardized mortality ratio (briefly called the S.M.R.), which is determined in the following manner. The death rates 
according to age for all males aged 20-65 are first calculated and then applied to the population enumerated in corresponding age periods for a specific occupation. The sum of the deaths thus obtained represents the number of " standard deaths" which would occur in that particular occupation if it were subject to average rates of mortality. The number of deaths which actually occurred is then expressed as a percentage of this standard number, and the result is termed the standardized mortality ratio for that particular occupation. So as to avoid the considerable chance fluctuations which would otherwise occur in their magnitude the RegistrarGeneral calculated these ratios only for occupational groups in which not fewer than 20 deaths had occurred from the particular cause considered. As a result a different set of occupations is considered for each disease and many small occupational groups are not included. This also precluded any analysis for the less common causes of death.

\section{METHOD OF ANALYSIS}

In this study two main problems present themselves. First there is the necessity for a direct comparison of the variation in mortality between the social classes with that within the social classes so as to assess the significance of a possible social-class gradient; this may be done by the analysis of variance. Secondly, it is important to discover if the variation within a social class indicates real differences in mortality, or is explicable as chance fluctuation only.

It was clear on examining the figures within each social class that they were not normally distributed, the range above the mean value being greater than that below it. Consequently the analysis of variance could not be directly applied to the actual standardized mortality ratios. By experiment it was found that when the logarithms of the ratios were used the distributions were approximately normal, although there was a slight tendency for each curve to be leptokurtic or sharply peaked. A comprehensive test after the analysis showed that in a total of 949 occupational groups, 33 (or $3.5 \%$ ) fell outside their respective ranges of mean \pm twice the standard deviation. If the distributions had been truly normal the figure would have been $4.5 \%$. The difference is not great, and it confirmed the initial decision that the téchnique of the analysis of variance could quite justifiably be applied to the logarithms of the standardized mortality ratios. All the calculations made were carried out on the logarithms. In the presentation of the results the mean logarithmic values have been converted back to standardized mortality ratios so as to show the gradients more clearly.

\section{Results}

The results of the first part of the analysis are given in Table I, which shows for each disease the mean S.M.R. in the three social classes. For the various diseases the trends in mortality, with one exception, agree with those obtained by the Registrar-General, who included all the deaths in each social class, and thus indicate that the omission in the present instance of the small occupations does not 
sensibly affect the results. The exception is influenza in married women, which shows a slight trend here, while the Registrar-General's figures do not suggest any correlation with social class. The significance test discussed below shows it to be an unimportant exception.

TABLE I

Standardized Mortality Ratios and the Significance of their Gradients with Social Class FOR CERTAIN Diseases

\begin{tabular}{|c|c|c|c|c|c|c|c|c|c|}
\hline \multirow[t]{2}{*}{ Cause of death } & \multicolumn{3}{|c|}{$\begin{array}{l}\text { No. of } \\
\text { occupational } \\
\text { groups in each } \\
\text { social class }\end{array}$} & \multicolumn{3}{|c|}{$\begin{array}{l}\text { Mean S.M.R. } \\
\text { for each } \\
\text { social class }\end{array}$} & \multirow{2}{*}{$\begin{array}{c}\text { Variance } \\
\text { Ratio }\end{array}$} & \multirow[t]{2}{*}{ Probability } & \multirow[t]{2}{*}{ Significance } \\
\hline & I \& & III & IV \& & $\begin{array}{l}\text { I\& } \\
\text { II }\end{array}$ & III & IV \& & & & \\
\hline \begin{tabular}{lr}
\multicolumn{2}{c}{ Men } \\
'Pulmonary & tuber- \\
$\begin{array}{l}\text { culosis } \\
\text { Cancer (all sites) }\end{array}$ &. \\
$\begin{array}{l}\text { Peptic ulcer } \\
\text { Bronchitis }\end{array}$ &. \\
Angina pectoris &. \\
$\begin{array}{l}\text { Diabetes } \\
\text { Appendicitis } \\
\text { Influenza }\end{array}$ &. \\
\end{tabular} & $\begin{array}{r}38 \\
47 \\
11 \\
9 \\
17 \\
9 \\
8 \\
17\end{array}$ & $\begin{array}{r}114 \\
113 \\
43 \\
38 \\
26 \\
15 \\
13 \\
41\end{array}$ & $\begin{array}{r}60 \\
55 \\
28 \\
29 \\
14 \\
7 \\
8 \\
23\end{array}$ & $\begin{array}{r}65 \\
83 \\
83 \\
61 \\
162 \\
182 \\
147 \\
100\end{array}$ & $\begin{array}{r}108 \\
105 \\
101 \\
101 \\
95 \\
102 \\
101 \\
96\end{array}$ & $\begin{array}{r}119 \\
108 \\
117 \\
140 \\
62 \\
75 \\
75 \\
103\end{array}$ & $\begin{array}{c}21 \cdot 76 \\
17 \cdot 83 \\
7 \cdot 27 \\
15 \cdot 26 \\
35 \cdot 84 \\
14 \cdot 92 \\
10 \cdot 21 \\
1 \cdot 31^{*}\end{array}$ & $\begin{array}{c}<0.001 \\
<0.001 \\
0.01>\mathrm{P}>0.001 \\
<0.001 \\
<0.001 \\
<0.001 \\
<0.001 \\
>0.2\end{array}$ & $\begin{array}{l}\begin{array}{l}\text { Highly } \\
\text { significant }\end{array} \\
\text { Not significant }\end{array}$ \\
\hline $\begin{array}{cr}\text { Wives } \\
\text { Pulmonary } & \text { tuber- } \\
\text { culosis .. } & . .\end{array}$ & 9 & 19 & $\dot{15}$ & 66 & 109 & 125 & $21 \cdot 39$ & $<0.001$ & Highly \\
\hline $\begin{array}{l}\text { Uterine cancer .. } \\
\text { Puerperal causes } \\
\text { Bronchitis } \\
\text { Breast cancer }\end{array}$ & $\begin{array}{r}6 \\
6 \\
4 \\
11\end{array}$ & $\begin{array}{r}9 \\
13 \\
6 \\
13\end{array}$ & $\begin{array}{l}9 \\
9 \\
9 \\
8\end{array}$ & $\begin{array}{r}91 \\
94 \\
76 \\
124\end{array}$ & $\begin{array}{r}96 \\
107 \\
116 \\
95\end{array}$ & $\begin{array}{r}114 \\
121 \\
172 \\
84\end{array}$ & $\begin{array}{l}1 \cdot 70 \\
3 \cdot 78 \\
4 \cdot 44 \\
7 \cdot 92\end{array}$ & $\begin{array}{c}>0.2 \\
0.05>P>0.01 \\
0.05>P>0.01 \\
0.01>P>0.001\end{array}$ & $\begin{array}{l}\text { Not significant } \\
\text { Significant } \\
\text { Highly }\end{array}$ \\
\hline Influenza & 6 & 7 & 7 & 104 & 110 & 122 & $1 \cdot 29 *$ & $>0.2$ & Not significant \\
\hline
\end{tabular}

* Variance estimate "within classes" greater than that "between classes".

As has been previously mentioned, the diseases were selected because they were numerically important and because the mortality from them exhibited varying degrees of correlation with socio-economic level. The significance of these trends is shown by the results of the analysis of variance between and within social classes for each cause of death. The observed gradients, with three exceptions, are statistically significant, and this is particularly true of the male experience. For example, the S.M.R. for bronchitis in men rises from 61 in Classes I and II to 140 in Classes IV and V. That is to say, in the most-favoured economic group the mortality is about $40 \%$ less, and in the least-favoured $40 \%$ greater, than the average for all men. The probability of $<0.001$ given by the analysis means that these differences would arise by chance less than once in a thousand cases. The three gradients which are not significant are those for influenza in men and in wives, and uterine cancer. Influenza is the only one of the selected diseases for which the 
Registrar-General's figures show no trend with social class in either sex, and so one would not expect to find significant gradients here. Uterine cancer does indicate a positive social-class gradient, but it lacks statistical significance, due in all probability to the small number of occupations on which the mean S.M.R.s were based. Thus it can be definitely asserted that apparent social-class gradients in these important causes of death do indicate real differences in mortality attributable to differing social and economic influences.

TABLE II

Coefficients of Variation in Mortality, and Values of $\chi^{2}$, within Social Classes for Certain Diseases

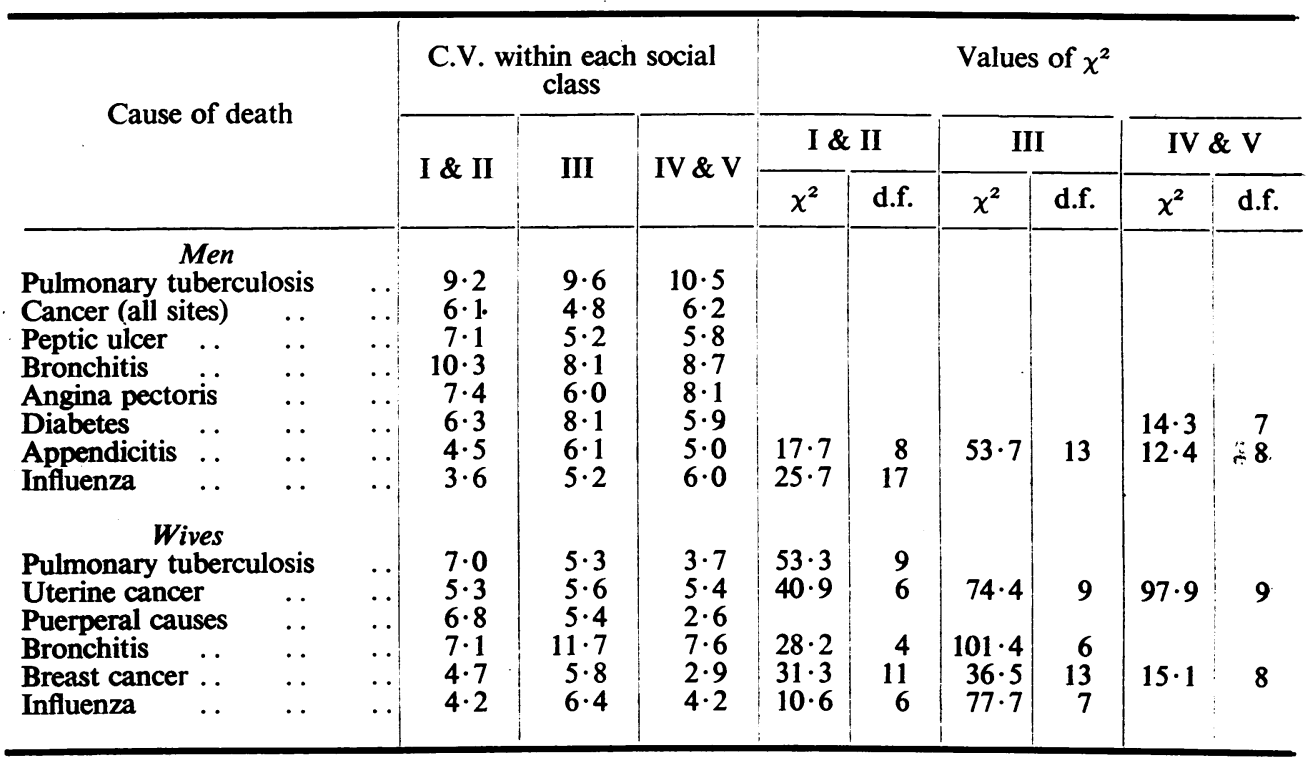

Table II contains the coefficients of variation within the social classes for ach cause of death. These coefficients do not on the whole indicate that the mortality is more variable within one social class than within another, though the values for pulmonary tuberculosis and puerperal causes in wives decrease from Classes I and II to Classes IV and V. There are, however, differences between the diseases. The mortality from pulmonary tuberculosis in men shows a relatively large variation, but that of their wives has average variation only. It would seem that occupational hazards are responsible for this, affecting the men but not their wives. The mortality from bronchitis, in both sexes, also shows more variation than do the other diseases. Presumably it is more influenced by changes in social and economic conditions within the social classes.

The question now arises whether these observed variations can be accounted for by chance fluctuation, or whether they are due to real differences in mortality between occupations in the same social class. From the discussion of pulmonary 
tuberculosis and bronchitis above it would seem that these mortalities do show real differences. This is only an impression, however, and requires statistical confirmation. The hypothesis to be tested is that the mortality is homogeneous throughout each social class. On this basis of homogeneity an expected number of deaths can be calculated for each occupation, by assuming that the population in that occupation experiences the age-specific death rates of the social group to which it belongs. This procedure would involve a great deal of labour; but a very close approximation to the expected number can be obtained much more simply. An example will make the method clear. The figures quoted are given in Table 4 of the Decennial Supplement for 1931.

In occupational group 17-metal moulders and die-casters (Social Class III)the standard deaths at ages 20-65 from influenza number 40; that is, 40 deaths would occur if the mortality was the same as that for all males. In Social Class III as a whole there occur 3,458 deaths from influenza, and the standard deaths are 3,660. Thus the mortality in Class III bears a ratio $\frac{3,458}{3,660}$ to that of all males. Hence $40 \times \frac{3,458}{3,660}=37 \cdot 8$ is the number of deaths expected if the occupation has the same mortality as Class III. (The exact method outlined in the previous paragraph also gives 37.8 expected deaths.) Now the actual number of deaths in group 17 is 66 , and so the fraction $\frac{(66-38)^{2}}{38}$ may be regarded as a contribution to a value of $\chi^{2}$.

It should be noted at this stage that a sum of contributions of this type will not be accurately distributed in the $\chi^{2}$ form. A complicating factor has been introduced since the " standard deaths" are standardized for age. However, the effect of this should be to make the expected deaths correspond even more closely with the observed deaths than a non-standardized estimate would, and thus makes it harder to establish significance with the $\chi^{2}$ test.

Contributions similar to that for group 17 may be calculated for each of the other 40 main occupations previously analysed for influenza in Class III. In addition a residual group should be included, comprising the aggregate of the minor occupations (those with fewer than 20 deaths) in the social class. Thus there are 42 contributions to $\chi^{2}$, and, since the totals of observed and expected deaths agree, the $\chi^{2}$ value will be based on at most 41 degrees of freedom. Because of the complication introduced by standardization it is not clear if further degrees of freedom should be subtracted in virtue of parameters estimated from the data, and no adjustment for this was made. Any error involved will be on the right side, since a reduction in the degrees of freedom would increase the significance of the values of $\chi^{2}$.

The majority of these values were found to be of overwhelming significance, and so it was not considered worth while to tabulate all of them. Table II contains a selection of values. Four of these fail to attain significance at the probability 
TABLE III

Occupations with Unusually High or Low Mortality Ratios for thieIR Social Class

\begin{tabular}{|c|c|c|c|c|c|}
\hline \multirow{2}{*}{ Cause of death } & \multirow{2}{*}{ Class } & \multicolumn{2}{|r|}{ High mortality } & \multicolumn{2}{|r|}{ Low mortality } \\
\hline & & S.M.R. & Occupation & S.M.R. & Occupation \\
\hline $\begin{array}{c}\text { Men } \\
\text { Pulmonary } \\
\text { tuberculosis }\end{array}$ & $\begin{array}{l}\text { I } \\
\text { III }\end{array}$ & $\begin{array}{c}148 \\
(364) \\
(396) \\
\\
867 \\
\\
750 \\
(757)\end{array}$ & $\begin{array}{l}\text { Inn and hotel keepers } \\
\text { Warehousemen (tex- } \\
\text { tiles, etc.) } \\
\text { Masons, etc., in sand- } \\
\text { stone (Lancs, Ches. } \\
\text { Yorks, W.R.) } \\
\text { Tin and copper mine } \\
\text { workers below } \\
\text { ground } \\
\text { Sand blasters } \\
\text { Grinders in manufac- } \\
\text { ture of cutlery }\end{array}$ & $\begin{array}{l}22 \\
37 \\
42\end{array}$ & $\begin{array}{l}\text { Managers of commer- } \\
\text { cial office depts. } \\
\text { Subordinate superin- } \\
\text { tending staff in coal } \\
\text { mines } \\
\text { Railway signalmen } \\
\\
\text { Gardeners and estate } \\
\text { labourers (pea and } \\
\text { fruit pickers) }\end{array}$ \\
\hline Cancer (all sites) & $\begin{array}{c}\text { I } \\
\text { III }\end{array}$ & $\begin{array}{l}169 \\
170 \\
176 \\
(220) \\
225 \\
(244) \\
214\end{array}$ & $\begin{array}{l}\text { Curriers, leather dres- } \\
\text { sers } \\
\text { Kiln and oven men } \\
\text { (earthenware, china, } \\
\text { etc.) } \\
\text { Chimney sweeps } \\
\text { Warehousemen (tex- } \\
\text { tiles, etc.) } \\
\text { Glass blowers and fin- } \\
\text { ishers } \\
\text { Puddlers-iron and } \\
\text { steel } \\
\text { Stevedores }\end{array}$ & $\begin{array}{l}(38) \\
43\end{array}$ & $\begin{array}{l}\text { Gardeners and estate } \\
\text { labourers (pea and } \\
\text { fruit pickers) } \\
\text { Warehouse and store- } \\
\text { keepers' assistants }\end{array}$ \\
\hline Peptic ulcer & $\begin{array}{c}\text { II } \\
\text { III } \\
\text { IV \& V }\end{array}$ & $\begin{array}{l}163 \\
182\end{array}$ & $\begin{array}{l}\text { Plasterers } \\
\text { Waiters }\end{array}$ & $\begin{array}{l}43 \\
67\end{array}$ & $\begin{array}{l}\text { Draughtsmen, costing } \\
\text { clerks } \\
\text { Agricultural and gar- } \\
\text { deners' labourers }\end{array}$ \\
\hline Bronchitis & $\begin{array}{l}\text { III \& IV } \\
\text { IV \& V }\end{array}$ & 343 & $\begin{array}{l}\text { Textile workers (fore- } \\
\text { men; overlookers; } \\
\text { card, comb, and } \\
\text { frame tenters-wool }\end{array}$ & 52 & $\begin{array}{l}\text { Agricultural and gar- } \\
\text { deners' labourers }\end{array}$ \\
\hline Angina pectoris & $\begin{array}{l}\text { I } \\
\text { II } \\
\text { III }\end{array}$ & $\begin{array}{l}368 \\
176\end{array}$ & $\begin{array}{l}\text { Physicians, surgeons } \\
\text { Hairdressers, etc. }\end{array}$ & 68 & Farmers and relatives \\
\hline
\end{tabular}




\begin{tabular}{|c|c|c|c|c|c|}
\hline Influẹnza & $\begin{array}{l}\text { III } \\
\text { IV } \\
\text { V }\end{array}$ & $\begin{array}{l}156 \\
165 \\
195\end{array}$ & $\begin{array}{l}\text { Masons, stone cutters, } \\
\text { dressers, carvers } \\
\text { Metal moulders, die } \\
\text { casters } \\
\text { Iron and steel foundry, } \\
\text { furnacemen and lab- } \\
\text { ourers }\end{array}$ & $\begin{array}{l}47 \\
58\end{array}$ & $\begin{array}{l}\text { Makers of textile goods, } \\
\text { dresses } \\
\text { Police }\end{array}$ \\
\hline $\begin{array}{c}\text { Wives } \\
\text { Pulmonary } \\
\text { tuberculosis }\end{array}$ & $\begin{array}{c}\text { III } \\
\text { IV \& V }\end{array}$ & 183 & $\begin{array}{l}\text { Occupation of husband } \\
\text { Warehousemen (tex- } \\
\text { tiles, etc.) }\end{array}$ & 83 & $\begin{array}{l}\text { Occupation of husband } \\
\text { Agricultural and gar- } \\
\text { deners' labourers }\end{array}$ \\
\hline Puerperal causes & III & 182 & $\begin{array}{l}\text { Coal hewers and get- } \\
\text { ters }\end{array}$ & & \\
\hline Bronchitis & IV \& V & & & 70 & $\begin{array}{l}\text { Agricultural and gar- } \\
\text { deners' labourers }\end{array}$ \\
\hline Breast cancer & III & & & 46 & $\begin{array}{l}\text { Locomotive engine } \\
\text { drivers, etc. }\end{array}$ \\
\hline
\end{tabular}

Occupational groups for which the S.M.R. is in parentheses form part of larger occupational groups and so were not used in the analysis.

level of 0.05 , two more are just significant at this level. The four non-significant values refer to appendicitis in Cंlasses IV and V for men, breast cancer in Classes IV and $\mathrm{V}$ for married women, and influenza in Classes $\mathrm{I}$ and II for both sexes. The two values just attaining significance apply to appendicitis in Classes I and II and diabetes in Classes IV and V, both for men. The remainder of the tabulated values, and all those not tabulated, are highly significant with $P<0 \cdot 01$.

The hypothesis that the mortality is homogeneous may be rejected in all the cases which attain significance. Thus, in all but four cases the analysis confirms that there are real differences in mortality within each social class.

Broadly speaking, the mortality differences between the social classes, as was shown earlier, may be regarded as due to the different social and economic levels, while those within the classes are due to a combination of socio-economic factors and occupational risks. An example of a factor causing differences in mortality within a social class is afforded by certain occupations being selective of personnel. Some types of employment are from the very nature of the work confined to persons who are physically fit, while others attract those who are less healthy. This consideration incidentally shows up an inherent defect in occupational mortality statistics. A man may contract a disease such as pulmonary tuberculosis - in one job, and then may move into another occupation which is not so strenuous, for his health's sake. Should he eventually die of tuberculosis, his death will be credited to his final occupation, and not to the one in which the disease was contracted. This defect can be overcome only by studying occupational morbidity rather than mortality.

In view of these mortality differences within the social classes it is of interest 
to identify the occupations which have particularly high or low mortalities for their social class. This was done on a uniform pattern by taking those occupations for which the logarithm of the S.M.R. differed from the mean by more than twice the standard deviation. These occupations are set out in Table III. Of the 949 occupational groups analysed 33 fall outside these ranges. Of these, 18 have particularly high, and 15 particularly low, mortalities. Certain of the small occupational groups, excluded from the analysis because they were included in larger occupations, also have specially high or low mortality ratios. Indeed it is often for this reason that the Registrar-General tabulated these smaller groups separately. In seven cases the mortality ratio for one or other of these groups fell outside the range based on the larger experience. These seven are also included in Table III. When the actual occupations are examined, the preponderance of outdoor occupations in the "low mortality" column is very striking. In the other column the occupations are more varied, but in few cases is it difficult to recognize the specific occupational hazard or poor environmental conditions responsible.

\section{SUMmaRY AND CoNClusions}

Variations in occupational mortality have been examined with particular reference to the social class of the occupation.

For a representative series of diseases the variation between three social classes was compared with that within those classes. The classes chosen were derived from the Registrar-General's five by amalgamating I with II and IV with V. The analysis confirmed that a clear social class gradient in the diseases considered indicated real mortality differences between the classes attributable to the different levels of social and economic environment. In one case (uterine cancer in wives) the evidence was not conclusive, probably because the analysis could only be based on a small number of occupations.

The variations in mortality within the chosen classes was examined for each disease by means of the $\chi^{2}$ test. It was clear in all but four cases that the observed variation could not be wholly accounted for by chance fluctuation, and that there were real mortality differences within each social class, attributable to differing social and economic conditions within the social classes combined with specific occupational risks. In view of this the occupations with particularly, high or low mortalities for their social class were identified and tabulated.

The main result of the study has been to show that though the social classes are not homogeneous from either an environmental or a mortality point of view, this does not invalidate the significance we may attach to a clear gradient in total social class mortalities.

I wish to thank Dr. W. T. Russell and Mr. D. J. Finney for their helpful criticism and advice in the preparation of this paper.

\section{REFERENCES}

Greenwood, M. (1939). Brit. med. J., 1, 862.

Registrar-General's Decennial Supplement: England and Wales, 1931. Part IIa, Occupational Mortality, H.M.S.O., 1938. 


\section{CORRECTION}

The reference in the top left-hand corner of the article by Barnet Woolf in the April issue of this journal was erroneously printed Brit. J. soc. Med. (1947), 2, 73-125. This should, of course, have been : Brit. J. soc. Med. (1947), 1, 73-125. The references on pages 126 and 135 were similarly misprinted. 